\title{
STAROŚĆ A PRZEMIANY WIĘZI SPOŁECZNYCH
}

$\mathrm{W}$ polskiej socjologii mamy obecnie do czynienia z dużym zainteresowaniem nowymi formami uspołecznienia i przemianami więzi społecznych. Zainteresowanie to dotyczy głównie wspólnotowości ludzi młodych i zapośredniczenia komunikacji przez media cyfrowe (Filiciak i in. 2010; Olcoń-Kubicka 2009). Przemiany więzi społecznych - powstające relatywnie nowe formy wspólnotowości oraz przekształcenia form „tradycyjnych”, takich jak wspólnota rodzinna i lokalna - w niemałym stopniu obejmują także ludzi starych. Chciałabym tu przyjrzeć się, jak wygląda podstawowa sfera życia ludzi starych — „sfera uspołecznienia”: do jakich wspólnot przynależą, w jakiego charakteru więziach społecznych uczestniczą. Rozpocznę od omówienia historycznych przemian tej sfery oraz przemian życia w późnym wieku w dobie nowoczesności w krajach zachodnich i w Polsce. Na tym tle przedstawię cztery zróżnicowane studia więzi społecznych starych kobiet zamieszkałych w Warszawie.

Ze względu na feminizację starości (zob. Tarkowska 2005) oraz odmienną socjalizację i bieg życia kobiet i mężczyzn należących do pokolenia osób starych starość różnych płci różni się w Polsce. Badania mówią, że przystosowanie do utraty współmałżonka częściej jest zadaniem dla kobiet, przejście na emeryturę częściej jest trudniejsze dla mężczyzn. Tutaj skoncentruję się na więziach starych kobiet, stanowiących zdecydowaną większość zbiorowości osób starych.

\section{HISTORYCZNE PRZEKSZTAECENIA SFERY USPOŁECZNIENIA}

Uspołecznienie to „procesy generujące koordynację działań jednostkowych” (Marody, Giza-Poleszczuk 2004, s. 10), które sprawiają, że „pewien ich zbiór

Adres do korespondencji: asia_zalewska@yahoo.com 
wyodrębnia się z otoczenia jako wewnętrznie zintegrowany system działań o bardziej lub mniej trwałym charakterze” oraz że „zbiór ten w działaniach orientuje się na obowiązujące wewnątrz niego, mniej lub bardziej rozpoznane, reguły interakcji (normy)" (Marody, Giza-Poleszczuk 2004, s. 40-41). Uspołecznienie w tym znaczeniu tworzy wspólnotę, społeczeństwo i każdą formę społeczną - piszą Mirosława Marody i Anna Giza-Poleszczuk, posługując się definicjami klasyków socjologii, Durkheima, Tönniesa, Simmla. Nacisk położony jest tu na proces zmienności, na powiązania między jednostką a grupą oraz między poszczególnymi jednostkami; społeczność traktuje się jako proces, a nie jako byt, którego statyczną strukturę należy badać.

Więzi społeczne to emocjonalnie nacechowane powiązania, które przekształcają motywacje człowieka i wymuszają na nim działania. Proces uspołecznienia polega na „emocjonalnym związywaniu jednostki [więziami społecznymi] z szerszą zbiorowością, wytwarzaniu uczuć społecznych oraz poczucia zbiorowego My. To właśnie od siły owego emocjonalnego związania zależy stopień zharmonizowania jej działań z działaniami innych ludzi, zgodność jej życiowych wyborów z podstawowymi cechami organizacji społeczności, jak również stopień podporządkowania jej interesów szeroko rozumianemu dobru wspólnemu zbiorowości" (Marody, Giza-Poleszczuk 2004, s. 94). Emocjonalne związanie jednostki opiera się na poczuciu winy i zobowiązania. Proces uspołecznienia ma formę emocjonalnego „imprintingu” — przebiega poza świadomą kontrolą socjalizujących i socjalizowanych.

Więzi społeczne wytwarzają podstawową formę uspołecznienia - wspólnotę. Wspólnota powstaje na bazie współobecności, współdziałania i współuzależnienia (komplementarność habitualnych działań jednostek podporządkowanych nadrzędnemu zadaniu, wynikająca z wzajemnego „docierania się") odrębnych i różnych jednostek. Wspólnota wyraża się w poczuciu jedności każdy członek wspólnoty czuje się związany z czymś, co istnieje ponad nim i co nie mogłoby przetrwać, gdyby nie stała współobecność i współdziałanie innych członków - oraz w poczuciu odrębności od świata zewnętrznego. Komplementarność działań wytwarza przyzwyczajenie i tradycję, towarzyszy jej wspólnota upodobań i wspólnota wiedzy oparta na pamięci wspólnego życia.

Autorki analizują historyczne przemiany form uspołecznienia, wyznaczone przechodzeniem z jednego typu społecznej organizacji do kolejnego: wspólnoty plemiennej, systemów wodzowskich, biurokracji agrarnych i społeczeństwa nowoczesnego. Przemianom towarzyszy pojawianie się obok wspólnot nowych rodzajów grup społecznych, w społeczeństwie przemysłowym są to na przykład stowarzyszenia oparte na relacjach, których istotą jest racjonalna wymiana. Zdaniem autorek, współcześnie mamy do czynienia z przemianą form uspołecznienia, czyli z wyłanianiem się kolejnego typu organizacji społecznej, być może obejmującego całą ludzkość, o czym świadczy „«rozmontowywanie» nowoczesnej formy uspołecznienia, by w jej miejsce mogła powstać forma nowa" (Marody, Giza-Poleszczuk 2004, s. 341). Wyłanianiu się nowych typów 
organizacji społecznej, a w nich nowych rodzajów grup społecznych, nie towarzyszy zanik wspólnotowości, wspólnota jest bowiem podstawowym rodzajem „związku społecznego” - wyznacza „ramy uspołecznienia” (Marody, Giza-Poleszczuk 2004, s. 142) przez wytwarzanie emocjonalnych powiązań jednostki $z$ całością.

Zmianom organizacji i złożoności świata społecznego muszą towarzyszyć dogłębne przekształcenia wspólnotowości. Zdaniem badaczek, mamy do czynienia $z$ rozrzedzeniem tego typu powiązań między ludźmi ze względu na powstawanie między poziomem rodziny a jednostką przetrwania kolejnych ugrupowań społecznych. „Jednostka przetrwania” to termin zaproponowany przez Norberta Eliasa na oznaczenie kolejno: plemienia, państwa i ludzkości. Na poziomie plemienia nie ma różnicy między jednostkowym uspołecznieniem $\mathrm{w}$ obrębie rodziny a uspołecznieniem $\mathrm{z}$ poziomu systemowego, na poziomie państwa nowoczesnego obok więzi rodzinnych i lokalnych mamy już relacje towarzyskie, relacje w pracy, następnie tzw. oddziaływania, na przykład w trakcie imprez masowych. Powstaje także nowy rodzaj więzi społecznych wytwarzających wspólnoty wyobrażone, których prototypowym przykładem są wspólnoty narodowe, łączące wszystkich członków jednostki przetrwania, jaką jest państwo. Do uczestnictwa we wspólnocie narodowej socjalizowano w rodzinie, wspólnotowość określa więc poziom najniższy i najwyższy organizacji społecznej. We wspólnocie narodowej poczucie jedności ze wspólnotą i odrębności wobec obcych nadal istnieje. Współuzależnienie i współdziałanie występują, jednakże jednostki nie obserwują ich bezpośrednio (ujawniają się na przykład w wypadku strajku), nie ma zaś współbycia — wyobrażenie go sobie jest możliwe dzięki zapośredniczonej wymianie symbolicznej.

Powstanie narodu jako wspólnoty wyobrażonej (Anderson 1997) wiązano z okresem wykształcania się nowoczesności, powstawania państw nowoczesnych. Niebagatelną rolę $w$ tym procesie odegrał druk i upowszechnienie możliwości komunikacji zapośredniczonej. Współcześnie mamy do czynienia $z$ istnieniem wielorakich podobnego rodzaju społeczności symbolicznych, jak nazywa je Kenneth Gergen (2009), nie przesądzając, czy są wspólnotami, podkreślając zaś, że ich członków łączy symboliczna wymiana słów, obrazów, informacji, zwykle w komunikacji zapośredniczonej. Fizyczna bezpośredniość i geograficzna bliskość jako wyznaczniki wspólnotowości tracą na znaczeniu. Przy czym fizycznej bezpośredniości i geograficznej bliskości nie trzeba utożsamiać ze współbyciem. Komunikacja zapośredniczona przez internet pozwala na współbycie, nie ma tam zaś fizycznej bezpośredniości i geograficznej bliskości. Co się dzieje ze współdziałaniem i współuzależnieniem?

Przy omawianiu przemian wspólnotowości nacisk kładzie się na tymczasowość i dobrowolność przynależności ${ }^{1}$, intensywną emocjonalność, zapośredni-

1 Twierdzenie, że uczestnictwo w poszczególnych wspólnotach jest dobrowolne, jest kwestią wyboru, wydaje się raczej elementem ideologii niż opisem rzeczywistości. O ile nowoczesne pań- 
czenie więzi przez przedmioty oraz masowe upowszechnienie i rozwój środków zapośredniczonej komunikacji. Marta Olcoń-Kubicka (2009) analizuje teorie charakteryzujące nowe formy wspólnotowości. Zasadne jest pytanie, czy teorie te opisują różne rodzaje nowo powstających wspólnot, czy też zwracają uwagę na odmienne aspekty nowych wspólnot. Autorka na podstawie analizy teorii oraz własnych badań nad forum internetowym skupionym wokół tematu macierzyństwa proponuje termin „wspólnota projektowa”, którym można objąć cechy takich zjawisk jak:

- uspołecznienie sieciowe Andreasa Wittela ${ }^{2}$;

- uspołecznienie poprzez relacje z obiektem w teorii Karin Knorr-Cetiny ${ }^{3}$;

— wspólnotowość ujęta w teorii „nowych plemion” Michela Maffesolego ${ }^{4}$.

Jakie cechy ma wspólnota projektowa? Olcoń-Kubicka wskazuje kilka: 1) tymczasowy charakter, łatwość wejścia i wyjścia; 2) koncentracja na pewnej idei (wspólnoty ideologiczne - ruch wegetariański, hobbystyczne - gracze gier fabularnych, terapeutyczne); 3) ewentualny charakter wyobrażeniowy; 4) charakter ekspresywny — dzielenie się przeżyciami za pomocą narracji, obok wymiany informacji i zasobów; 5) intersubiektywizacja doświadczenia na bazie zjawiska projekcji i identyfikacji; 6) wytworzenie się wspólnego dyskursu poprzez wspólne zajmowanie się daną ideą (współwiedza); 7) koordynacja działań. Autorka stwierdza, że nie ma tutaj solidarności (poczucia jedności) i więzi moralnej. Ponieważ w klasycznych definicjach o wspólnocie decyduje istnienie więzi moralnych (emocjonalnych powiązań skłaniających do działania na rzecz wspólnoty za sprawą poczucia zobowiązania), to sądzę, że wspólnotowości trzeba albo szukać gdzie indziej — tam gdzie działa poczucie zobowiązania, albo założyć, że coś innego zaczyna konstytuować więzi społeczne i motywować do działania na rzecz dobra wspólnego.

Idąc w pierwszym kierunku, za Kennethem Gergenem (2009, s. 80) zwrócę uwagę, że współcześnie wzrosła liczba zobowiązań. Wynika to ze społecznego nasycenia, czyli wystawienia jednostki w stopniu większym niż kiedykolwiek

stwo narodowe kreowało taki sposób mówienia, który pozwalał wspólnotę narodową przedstawiać jako egalitarną, o tyle obecnie obowiązujący sposób mówienia o dobrowolnym wyborze grup przynależności ma podobne zadanie - ukryć działające mechanizmy reprodukcji ładu społecznego (Bourdieu, Passeron 1990). Przystąpienie do wspólnoty wymaga społecznego rozpoznania, które dokonuje się na bazie nieświadomie ocenianych oznak kapitału kulturowego jednostki.

2 Polega ono na koordynacji działań w celu realizacji projektu i jest charakterystyczne dla pracy w sektorze usługowym, jego cechy można znaleźć także poza sferą pracy, na przykład w grupach terapeutycznych.

3 Obiekty to specyficzne przedmioty, które podlegają stałym przekształceniom, są nieokreślone i wymagają stałego udoskonalania; obiekty zastępują ludzi jako partnerzy w relacjach oraz środowiska przynależności i jednocześnie pośredniczą w relacjach międzyludzkich; jednostka angażuje się $\mathrm{w}$ relację $\mathrm{z}$ obiektem, odpowiadając na jego niedokończoność; prototypowym obiektem jest obiekt badań naukowych.

4 Nowe plemiona to tymczasowe wspólnoty uczuciowe oparte na podzielaniu pasji — więc ograniczone do pewnego aspektu życia, wyrażające się w zbiorowym doświadczaniu wrażeń. 
na opinie, wartości i style życia innych, oraz z „zaludniania Ja”, czyli odzwierciedlającego zasysania cząstkowych tożsamości innych. Zawieramy w sobie tłumy, twierdzi Kenneth Gergen, są to zarówno osoby, z którymi się kontaktujemy, jak i postaci z mediów. Wystawienie na kontakty sprawia, że mamy obowiązek coś zrobić dla wielu osób; zaludnianie Ja oznacza wielość pożądanych wzorców zachowań, z których wszystkich nie jesteśmy w stanie spełnić. Jednakże w przyszłości, zdaniem autora, nastąpi przemiana funkcjonowania aparatu psychicznego i powstanie Ja relacjonalne - jako wynik niemożności utrzymania stabilnej tożsamości w obliczu uczestnictwa w różnorodnych, zmieniających się warunkach i powiązaniach. Nie będziemy już wyodrębniać jednostek i ich zobowiązań, istnieć będą konteksty i grupy, których będzie się częścią. „Przyszły człowiek" automatycznie będzie się stawał członkiem wspólnoty, w której otoczeniu się znajdzie, za pomocą „relacjonalnego” aparatu psychicznego.

$\mathrm{Na}$ czym mogą się opierać więzi społeczne, jeśli nie na poczuciu zobowiązania? Motywem pojawiającym się w kilku teoriach jest koncentracja wokół idei i projektu: projekty związane $z$ pracą $w$ usługach, badania naukowe czy podzielane ideologie. Teoria uspołecznienia w relacji z obiektem Karin Knorr-Cetiny (1997) opisuje mechanizm, który motywuje jednostki do działania dla „dobra wspólnego", i ten mechanizm „pasuje” do wspólnot projektowych (Olcoń-Kubicka 2009). „Obiekt”, czyli projekt lub idea, dla których grupa lub jednostka działa, poprzez swoją permanentną niedokończoność ma strukturę braku. Struktura braku wyzwala w jednostce „strukturę chcenia” (structure of wanting), aby ten brak uzupełnić. W ten sposób więź z obiektem jest komplementarna, powstaje współuzależnienie: stan obiektu-odpowiedź jednostki. Współdziałanie jest konieczne do realizacji projektu, zarówno w diadzie człowiek-obiekt, jak i we wspólnocie wokół danego obiektu. Wspólnota projektowa, w której natura więzi polega na zaangażowaniu w obiekt, spełniałaby więc „wysokie” kryterium wspólnotowości — działania na rzecz dobra wspólnego przez angażowanie się we wspólny i wartościowy dla wszystkich członków wspólnoty projekt. W takim typie związania ze wspólnotą więź oparta byłaby nie na poczuciu zobowiązania, lecz na pewnym „nieodpartym przyciąganiu”, na pragnieniu odpowiedzi na strukturę braku.

\section{WYŁONIENIE SIĘ STAROŚCI JAKO ODRĘBNEJ FAZY ŻYCIA W DOBIE NOWOCZESNOŚCI}

Wyłonienie się starości jako odrębnej fazy życia na przełomie XIX i XX wieku w Wielkiej Brytanii i Stanach Zjednoczonych było konsekwencją wzrostu liczby osób starych w populacji oraz przemian związanych $z$ industrializacją warunków i sposobu życia. Industrializacja wpłynęła na zubożenie osób starych z klasy pracującej, do której powstania się przyczyniła. Praca w fabrykach wymagała siły i szybkości, starsi robotnicy byli wypychani z rynku pracy. Pomiędzy rokiem 1880 a 1920 w Stanach Zjednoczonych niemal jedna trzecia 
osób w wieku $65+$ pobierała zasiłki dla biednych. Chris Gilleard i Paul Higgs (2005) twierdzą, że powszechna emerytura pojawiła się jako kwestia polityczna w społeczeństwie klasowym. Chodziło o inkorporację klasy pracującej w struktury państwa nowoczesnego. Uchwalenie powszechnej emerytury miało znaczenie kulturowe: człowiek stary przestał być biedakiem, a stał się emerytem ${ }^{5}$.

Ustanowienie emerytur miało duży wpływ na życie rodzinne ludzi starych (Finch 1994). W połowie XIX wieku byli oni zaangażowani w struktury rodzinnego wsparcia na zasadzie wzajemności. Jeszcze na początku XX wieku stare kobiety żyły niekiedy bez jakiegokolwiek źródła dochodu za sprawą wkładu pracy $\mathrm{w}$ gospodarstwa domowe krewnych. Wprowadzenie powszechnie dostępnych emerytur uniezależniło od rodziny utrzymanie się na starość, co mogło przyczynić się do rozluźnienia więzi między ludźmi starymi a ich dziećmi oraz zacieśnienia więzi w rodzinie nuklearnej. Inne istotne zmiany w prawie i zatrudnieniu, które w tym okresie miały wpływ na wspólnoty rodzinne, to powszechny obowiązek szkolny i zakaz pracy dzieci, w 1918 r. wprowadzony w Anglii. Wyrugowało to wzajemność z relacji rodzice-dzieci - dzieciństwo i młodość stały się czasem jednostronnej zależności bez konieczności wkładu dzieci w utrzymanie rodziny. Te zmiany, kluczowe dla określenia relacji między pokoleniami $\mathrm{w}$ rodzinie - powszechne emerytury, powszechna edukacja dzieci, zakaz pracy dzieci - wykluczyły najmłodsze i najstarsze pokolenie z rynku pracy, odbierając im możliwość samodzielnego zdobywania środków do życia. Przy czym dzieci stały się materialnie zależne przede wszystkim od rodziców, ludzie starzy zaś od państwa.

Tamara Hareven (1982) opisuje zmiany, które zaszły na przestrzeni $\mathrm{XX}$ wieku, a były zapoczątkowane przez wspomniane wyżej interwencje państwa nowoczesnego na przełomie wieków. Główną zmianą był zanik współzależności krewnych, z którymi więzi w XIX wieku stanowiły dla jednostki podstawę zabezpieczenia. Obecnie zabezpieczenie zapewnia państwo. W dziewiętnastowiecznej rodzinie istniały relacje instrumentalne, a ważne momenty przejścia w życiu jednostek, takie jak zawarcie małżeństwa czy podjęcie pracy, podporządkowane były dobru wspólnemu rodziny, gdyż od tego zależało przetrwanie jej członków. W XX wieku państwo „wyjęło” jednostki z więzi instrumentalnych w rodzinie: nastąpiła segmentacja przebiegu życia na poszczególne stadia (dzieciństwo, młodość, starość, wiek średni) i uniformizacja wieku ważnych przejść życiowych jednostki, które $\mathrm{w}$ ten sposób przestały służyć interesowi rodziny jako jednostki przetrwania, a zaczęły być regulowane przez państwo.

\footnotetext{
5 Państwowe emerytury w Niemczech wprowadził Bismarck jeszcze w XIX wieku, we Francji dla osób starych niezdolnych już do pracy wprowadzono je w 1905 r., w Anglii w 1908 r. dla osób po siedemdziesiątym roku życia, w Stanach Zjednoczonych dopiero w 1935 r. ze względu na powszechne tam wcześniej renty dla weteranów wojennych oraz istnienie prywatnych funduszy emerytalnych. W Polsce jednolity dla całego kraju system emerytalny obowiązuje od $1933 \mathrm{r}$.
} 
W społeczeństwie nowoczesnym starość jest wyraźnie oddzielona od poprzednich stadiów życia, wyznacza ją emerytura, która zbiega się w czasie $z$ odejściem dzieci z domu, czyli powstaniem syndromu pustego gniazda i przybraniem nowej roli społecznej babci i dziadka. Mamy więc do czynienia z wyraźną nieciągłością - ostrym przejściem $z$ wieku średniego do starości we wszystkich sferach życia oraz z uniformizacją tego przejścia w skali całych społeczeństw: starość przychodzi dla wszystkich w tym samym momencie wraz $z$ osiągnięciem wieku emerytalnego. W czasach przednowoczesnych bieg życia nie był tak nieciągły, a początek starości nie był zuniformizowany. Pracowano aż do zniedołężnienia i śmierci, „kobiety wydawały na świat dzieci w przeciągu całego okresu rozrodczego" (Szukalski 2002, s. 165), role matki małych dzieci i babki zachodziły na siebie, $\mathrm{w}$ związku z tym problem pustego gniazda nie był powszechny, wręcz przeciwnie zdarzało się, że starzy rodzice umierali, mając jeszcze w gospodarstwie domowym niedorosłe dzieci. Wynikiem interwencji państwa nowoczesnego jest więc rozdzielenie starości społecznej (emerytura) i starości biologicznej (zniedołężnienie, choroby wieku podeszłego).

\section{TRZECI WIEK I KULTURA MŁODOŚCI}

Opisując sytuację w Wielkiej Brytanii Chris Gilleard i Paul Higgs (2005) wskazują, że aż do lat siedemdziesiątych XX wieku ludzie starzy byli kategorią homogeniczną: $\mathrm{w}$ większości biedni, podobnie wyglądający, o podobnych poglądach, z ograniczonymi aspiracjami co do przyszłego stylu życia. Sytuację tę diagnozowała teoria strukturalnej zależności (Gilleard, Higgs 2000), która wskazując na niski poziom emerytur, mówiła o marginalizacji osób starych przez rozwiązania polityki społecznej. W ciągu kolejnych dwudziestu lat sytuacja się zmieniła, już w latach osiemdziesiątych większość brytyjskich emerytów pobierała emeryturę $z$ dwu filarów: państwową i prywatną (fundusze zakładowe, sektorowe i prywatne). Emerytura państwowa pozostała na poziomie zabezpieczenia minimalnego, drugi filar zaś był bardzo zróżnicowany, wysokość jego świadczeń była wynikiem starań związków zawodowych, które dbały o podwyżki zarobków i wyższy wkład pracodawców w fundusze emerytalne. W latach dziewięćdziesiątych wśród emerytów w Wielkiej Brytanii istniało ogromne zróżnicowanie dochodowe. Dochód 20\% najbiedniejszych pochodził tylko z państwowej emerytury, a wśród 20\% najbogatszych dwie trzecie dochodu pochodziło $z$ prywatnych źródeł, takich jak fundusze zakładowe, indywidualne, renty, inwestycje - ci emeryci byli naprawdę zamożni. Teoria strukturalnej zależności stała się nieadekwatna do analizy statusu ludzi starych.

W drugiej połowie XX wieku zaszły nie tylko zmiany ekonomiczne, które wpłynęły znacząco na życie na emeryturze, nastąpiła także zmiana pokoleniowa w zakresie przebiegu życia. W obrębie roczników urodzonych pod koniec XIX i na przestrzeni XX wieku Gilleard i Higgs (2005) wyodrębnili dwa oddzielne 
pokoleniowe pola kulturowe. Sięgnęli tu po pojęcie Pierre'a Bourdieu. Jednostki przynależące do odmiennych pól pokoleniowych mają odmienny kulturowy habitus, czyli zbiór dyspozycji, które tworzą i strukturyzują indywidualne praktyki.

Wcześniejsze pole pokoleniowe (P1) zostało ukształtowane we wczesnej nowoczesności. To urodzeni w latach 1880-1960, w których mamy do czynienia $z$ kontynuacją przebiegu życia przez kolejne wchodzące $\mathrm{w}$ życie generacje, można więc mówić o ciągłości doświadczeń życiowych ojców i synów oraz matek i córek. Młodzież od wczesnych lat pracowała, młodość była treningiem do życia opartego na pracy. Przebieg życia kobiet i mężczyzn był zasadniczo odmienny. Mężczyźni z klasy pracującej większość życia spędzali na pracy fizycznej, mając ograniczony czas wolny i możliwości rekreacji. Przejście na emeryturę można $\mathrm{w}$ ich przypadku traktować jako upadek autonomicznego podmiotu społecznego. Dla kobiet głównym doświadczeniem były małżeństwo, dom, dzieci. W gospodarstwie domowym nie było jeszcze udogodnień (dopiero $\mathrm{w}$ latach pięćdziesiątych-sześćdziesiątych w Europie rozpowszechniły się sprzęty gospodarstwa domowego), więc także ich życie było wypełnione pracą - w domu. Do lat pięćdziesiątych ważną rolę odgrywały wspólnoty lokalno-rodzinne, skupione wokół kobiet, oparte na współdziałaniu i wspólnym przebywaniu; badania brytyjskie wskazują bowiem, że w miastach uprzemysłowionych członkowie rodziny zamieszkiwali często w tej samej lokalności, więc więzi sąsiedzkie były tożsame $z$ więziami rodzinnymi. Środki masowego przekazu były wówczas w Wielkiej Brytanii słabo dostępne.

Rozluźnienie więzi we wspólnotach lokalnych, postępujące od lat pięćdziesiątych, jest tłumaczone wzrostem mobilności - młodsze pokolenia przestały osiedlać się $\mathrm{w}$ sąsiedztwie starszych, nastąpiło więc rozdzielenie więzi rodzinnych i lokalnych - oraz wzrostem solidarności wewnątrzpokoleniowej (wzrost znaczenia relacji mąż-żona kosztem relacji matka-córka). Tym zmianom towarzyszyło rozpowszechnienie radia i telewizji, co skutkowało ograniczeniem czasu spędzanego $\mathrm{w}$ przestrzeni sąsiedzkiej.

Rozdzielenie więzi rodzinnych i lokalnych pociągało za sobą nie tylko zanik więzi sąsiedzkiej i anonimowość w miejscu zamieszkania, ale także przekształcenia więzi rodzinnej, która swój charakter zachowała jedynie w rodzinie nuklearnej. Między pokoleniami czy dorosłym rodzeństwem bezpośredni fizyczny kontakt zastąpiły bardziej elastyczne sposoby „pozostawania w kontakcie” rozmowy telefoniczne, wizyty. Jednostki zyskały większą niezależność, a powiązania przyjęły charakter ekwiwalentnej wymiany. Zgodnie z definicją Tönniesa można w tym wypadku mówić raczej o relacjach niż o więziach.

Przemiana więzi rodzinnych nastąpiła w tym samym czasie co zmiana pokoleniowa, czyli wyodrębnienie pokolenia kultury młodości (P2). Gilleard i Higgs argumentuja, że młodzi ludzie jako jednolita kategoria pojawili się w latach pięćdziesiątych jako produkt nowego rynku - twór reklamy i mediów, co było możliwe dzięki wzrostowi zamożności społeczeństwa i jednoczącemu do- 
świadczeniu szkolnemu. Pole pokoleniowe kultury młodości i masowe społeczeństwo konsumpcyjne mają wspólne korzenie. Wykształciły się początkowo w Stanach Zjednoczonych, a następnie w Europie Zachodniej. Młodość stała się dominującą wartością, wyzwaniem rzuconym starszym; celem było odróżnić się od starszych pokoleń i ich wartości przez konsumpcyjne uczestnictwo w kulturze popularnej. W Wielkiej Brytanii gusta muzyczne, dotyczące jedzenia, filmów i mody były przejmowane ze Stanów Zjednoczonych. Amerykańska kultura młodości, w której dużą rolę odgrywały kwestie rasowe i klasowe (powstawała w latach 1940-1965), w brytyjskim kontekście była odbierana jako kolor, ekscytacja, zabawa, seksualność, wolność. W tym pokoleniu doświadczenie kobiet i mężczyzn było podobne, znacząco różniło się natomiast od doświadczenia ich rodziców i dziadków. W latach sześćdziesiątych większość młodzieży uczęszczała do szkoły średniej. Pracę zaczynali często jako blue-collar workers, ale dokształcali się i awansowali na white-collar workers. Ze względu na zmianę struktury zatrudnienia zanikała klasa pracująca. Upowszechniły się udogodnienia $\mathrm{w}$ gospodarstwie domowym i mass media. Młode lata spędzone w szkole średniej, bez obowiązku pracy zarobkowej, to dla tego pokolenia trening do trwającej całe życie konsumpcji.

Habitus wykształcony przez kulturę młodości wyznaczał praktyki wieku średniego przedstawicieli pokolenia kultury młodości. Po przejściu na emeryturę ten sam habitus decyduje o kontynuacji praktyk konsumpcyjnych. Wraz $\mathrm{z}$ wejściem pokolenia kultury młodości $\mathrm{w}$ wiek emerytalny mamy do czynienia z kontynuacją indywidualnego stylu życia, zorientowanego na konsumpcję - mówimy o trzecim wieku. Obok lub po trzecim wieku istnieje czwarty wiek, charakteryzujący się niemożnością uczestnictwa w praktykach konsumpcyjnych ze względu na stan zdrowia, niski kapitał ekonomiczny i kulturowy. Obecnie kolejne roczniki wkraczające w życie są socjalizowane do uczestnictwa w kulturze młodości.

Wyłanianiu się pokolenia kultury młodości towarzyszył zanik znaczenia wspólnot lokalnych i rodzinnych oraz upowszechnianie się wspólnot symbolicznych. Obecnie antropologowie opisują zjawisko przeciwne, charakterystyczne dla współczesnego świata zachodniego, dla Francji, Wielkiej Brytanii i Stanów Zjednoczonych: upowszechnianie się wspólnot rówieśniczych osób starych, opartych na wspólnym przebywaniu. W społecznościach zgromadzonych $\mathrm{w}$ nursing homes i residential homes mamy do czynienia $\mathrm{z}$ wykształceniem się wspólnot, które we wszystkich trzech wymienionych krajach mają bardzo podobne cechy (Keith 1980a; Hochschild 2000; Hazan 1990): 1) wspólne doświadczenia: starzenie się fizyczne, starość społeczna (przystosowanie do emerytury, problematyczne relacje $z$ dziećmi), umiejscowienie historyczne (doświadczenie dwóch wojen i depresji gospodarczej); 2) decyzja o zamieszkaniu w ośrodku dla ludzi starych często wymuszona i nieodwracalna; 3) intensywne życie społeczne w ośrodku; 4) własne przedstawicielstwo; 5) praca na rzecz ośrodka; 6) współzależność: pomoc w chorobie, wymiana dóbr i usług, 
więzi emocjonalne; 7) kontakty społeczne intensywniejsze wewnątrz niż na zewnątrz ośrodka; 8) świat zewnętrzny jako zagrożenie; 9) wspólne symbole (Keith 1980b).

Można sądzić, że wspólnoty rówieśnicze ukształtowane na bazie wspólnego przebywania i współdziałania dla dobra wspólnoty przez odtwarzanie sensu są charakterystyczne dla czwartego wieku, przynależą do nich osoby wychowane przed końcem lat pięćdziesiątych w rodzinach, w których wspólnota rodzinna i wspólnota lokalna pokrywały się, a wspólnotowość oparta była na geograficznej bliskości i fizycznej bezpośredniości. Dla trzeciego wieku charakterystyczne jest uczestnictwo we wspólnotach symbolicznych, w których komunikacja jest zapośredniczona.

Podsumujmy: mamy do czynienia ze stopniową zmianą - ważne przejścia $w$ życiu jednostki wraz z nastaniem nowoczesności przestają być podporządkowane cyklowi rodziny, zaczyna je wyznaczać wiek jednostki w kształcie nadanym przez regulacje państwa nowoczesnego, stają się zuniformizowane. $\mathrm{W}$ następstwie zmian $\mathrm{w}$ prawie i zatrudnieniu zachodzi przemiana układu zależności między pokoleniami w rodzinie, co prawdopodobnie przyczynia się do ograniczenia do rodziny nuklearnej powiązań typu więzi. W drugiej połowie XX wieku upowszechniają się (1) przemiany więzi rodzinnej: od więzi opartej na codziennym współbyciu, współzależności i współpracy do relacji realizowanej przez „pozostawanie w kontakcie”; (2) przemiany wspólnotowości: od dominacji wspólnot opartych na bezpośredniości fizycznej i bliskości geograficznej do upowszechnienia wspólnot symbolicznych i o zapośredniczonych więziach; (3) przemiany przebiegu życia oparte na zmianie charakteru procesu uspołecznienia: od treningu do pracy - gdy mechanizmem sprawczym było prawdopodobnie poczucie zobowiązania wobec wspólnoty rodzinnej i narodowej $-\mathrm{w}$ stronę treningu do konsumpcji. Zmiany te były opisywane na przykładzie klasy pracującej, w awangardzie znajdowała się klasa średnia, często istotę owych zmian stanowiło upowszechnienie charakterystycznego dla niej wzorca.

Antropolog powinien być czuły na kontekst globalny — stąd obszerne omówienie pozycji osób starych w społeczeństwach Stanach Zjednoczonych i Wielkiej Brytanii, wszak przeobrażenia tam zachodzące mają wpływ na życie społeczne także u nas. Przyjrzyjmy się teraz niektórym jego lokalnym aspektom.

\section{SPECYFIKA STAROŚCI W POLSCE}

Podczas gdy w Stanach Zjednoczonych i Anglii na początku XX wieku powstały warunki sprzyjające zanikowi zależności ludzi starych od ich rodzin, o czym pisała Tamara Hareven, na polskiej wsi funkcjonowała w tym czasie rodzina wielopokoleniowa (Szynkiewicz 1976): przy rodzicach zamieszkiwał syn z żoną i dziećmi. Ukształtowała się ona w czasie przechodzenia od stosunków feudalnych do kapitalistycznych na wsi, pełniła funkcję zabezpieczania starych 
jej członków, wcześniej spoczywającą nie tylko na dzieciach, ale także na dworze i społeczności wiejskiej. W gospodarstwie istniał podział ról oparty na kryteriach wieku, płci i pozycji w rodzinie, od wykonanej pracy zależał zakres udziału w konsumpcji. Osoby starsze zajmowały się pracami posługowymi i opieką nad dziećmi (zob. Szynkiewicz 1976; Zawistowicz-Adamska 1948; Olędzki 1991).

Jeszcze w latach sześćdziesiątych większość ludzi starych w Polsce (67\%) mieszkała wspólnie z dziećmi, najczęściej w środowisku chłopskim, najrzadziej wśród pracowników umysłowych w środowisku miejskim (Piotrowski 1973). Wspólne zamieszkiwanie traciło charakter rodziny wielopokoleniowej (dwukrotnie częstsze w przypadku rodzin chłopskich), były to zwykle rodziny rozszerzone. W rodzinach chłopskich wspólne zamieszkiwanie miało charakter trwały i instytucjonalny, w mieście - przejściowy, ze względu na trudności mieszkaniowe, pomoc $\mathrm{w}$ gospodarstwie domowym pracującej córki lub konieczność pielęgnacji starego rodzica. Zjawisko wspólnego zamieszkiwania i świadczeń materialnych, zdaniem Jerzego Piotrowskiego, zaczęło zanikać na rzecz wymiany symbolicznej i świadczeń emocjonalnych; rodzina przestawała być związkiem „grup małżeńskich”, a stawała się związkiem indywidualnym, w którym wzajemna pomoc nie opiera się na normach obyczajowych, lecz na osobistych uczuciach.

Genezy przemian obyczajowych w polskich miastach w latach sześćdziesiątych Marcin Czerwiński (1969) upatruje: w przeniesieniu edukacji poza rodzinę - młode pokolenie nie terminuje u mistrza, ale „u całego społeczeństwa”, za pośrednictwem szkoły i środków masowego przekazu; $\mathrm{w}$ upowszechnieniu sprzętów gospodarstwa domowego zmniejszających zakres prac domowych, co zaowocowało masowym podjęciem pracy przez kobiety. Stosunki rodzinne straciły na wadze na rzecz stosunków koleżeńskich. Ze względu na postęp techniczny i zmiany stosunków produkcji w cenie była młodość społeczna, charakteryzująca się elastycznością i ciągłą zdolnością do przyswajania nowości. Obserwacje te można potraktować jako opis rozwoju kultury młodości w Polsce. Trudno dopatrzyć się w niej jeszcze indywidualizmu zorientowanego na konsumpcję, są przemiany więzi w rodzinie w stronę relacji, konieczność dokształcania się sugeruje wspólnoty projektowe, a środki masowego przekazu zapośredniczenie więzi.

Trwałość rodzin wielopokoleniowych na wsi jest związana między innymi $z$ faktem, że rolników indywidualnych późno objęto ubezpieczeniem emerytalnym, dopiero w 1977 r. (Czepulis-Rutkowska 2000, s. 69). Na niektórych obszarach kraju, na przykład we wsiach Beskidu Śląskiego i Podhala (Lehr 2007), powoli zanikające rodziny wielopokoleniowe możemy obserwować jeszcze dzisiaj. Byt mieszkających tam pod jednym dachem kolejnych pokoleń nie jest już zdeterminowany zasadami funkcjonowania gospodarstwa, które niegdyś definiowały rolę każdego członka rodziny, ponieważ znaczna część mieszkańców wsi pracuje poza rolnictwem. Jednak osoby stare, chociaż pobierają emerytury, nadal są przekonane, że miarą pozycji w rodzinie jest stopień zaangażowania 
$\mathrm{w}$ pracę $\mathrm{w}$ gospodarstwie, a zaniechanie gospodarowania na roli przez młodych pracujących poza rolnictwem to dla nich pogwałcenie podstawowych wartości.

Na początku XXI wieku $44 \%$ emerytów w Polsce mieszkało z innymi niż współmałżonek osobami (Błędowski 2002) i były to zazwyczaj dzieci (41\%). Od czasów badań Jerzego Piotrowskiego wśród osób starszych znacznie wzrosła liczba gospodarstw jedno- i dwuosobowych: w 1967 r. stanowiły 47\%, a w 2001 r. - 73\% gospodarstw, w których mieszkali emeryci. Jednocześnie od lat sześćdziesiątych z $30 \%$ do $38 \%$ wzrósł w populacji ludzi starych udział osób, które często przebywają same w domu, ale odczuwanie osamotnienia nie jest bardziej powszechne (20\% w 1967 r., 17\% w 2002 r.) (Czekanowski 2002). Dane te potwierdzają tezę Jerzego Piotrowskiego o zmianie modelu rodziny.

\section{PRZEMIANY STAROŚCI W KONTEKŚCIE PRZEMIAN FORM USPOŁECZNIENIA - BADANIA ETNOGRAFICZNE W WARSZAWIE}

Jak w kontekście przemian więzi rodzinnych wygląda obecnie życie na starość? Do jakich wspólnot przynależą osoby stare? Na czym opierają się więzi społeczne w tych wspólnotach, czy można mówić o więzi moralnej? Na czym polega mechanizm koordynujący uczestnictwo jednostki we wspólnocie, co ją motywuje do działania (dla dobra wspólnego)? Spróbuję udzielić odpowiedzi analizując sferę uspołecznienia starych kobiet w Warszawie ${ }^{6}$. Skoncentruję się na małej liczbie celowo dobranych przykładów, ponieważ dążę do zrozumienia charakteru więzi społecznych. Inspiracje czerpię z etnografii wielostanowiskowej (Marcus 2003), która jest metodą prowadzenia badań w warunkach nieciągłości formacji kulturowych, gdy ponadlokalne czynniki wpływają na sytuację w danej lokalności, wywołując rozmaite "praktyki, niepokoje i dwuznaczności” (Marcus 2003, s. 170).

W Warszawie mamy do czynienia z różnym stopniem nasilenia współuzależnienia, współdziałania i współbycia we wspólnotach rodzinnych. Dwie modelowo odmienne pod tym względem sytuacje starości omówię na przykładach dwóch historii: pani Ludmiły, której powiązania rodzinne można określić jako więzi wyrażone poprzez współbycie, współuzależnienie i współdziałanie, i pani Antoniny, której powiązania z członkami rodziny można określić jako bliższe relacji.

${ }^{6}$ Badania terenowe nad życiem codziennym osób starych w Warszawie były prowadzone w latach 2004-2007. Pierwszy etap zrealizowano z udziałem studentów Instytutu Etnologii i Antropologii Kulturowej UW w ramach laboratorium etnograficznego. Badania prowadzone były w instytucjach i przestrzeniach prywatnych. Drugi etap dotyczył życia codziennego na starość w jedenastu odmiennych kontekstach wyznaczonych przez główne aktywności orientujące życie na starość: aktywność rodzinna, zawodowa, społeczna, skupiona wokół gospodarstwa domowego, towarzyska, towarzyska w ramach instytucjonalnych, religijna, edukacyjna/hobby/samorealizacja, samotnicza, wspomnieniowa, choroba. 
Pani Ludmiła, urodzona tuż przed wojną, pochodzi z rodziny rzemieślniczej z małego miasta, do Warszawy przyjechała „za pracą” męża w Hucie Warszawa. Obecnie jest wdową, mieszka sama, pozostaje jednak w codziennym kontakcie z rodziną: córką, zięciem i wnukami. Córka przychodzi co drugi dzień, dzwoni codziennie rano, pomaga finansowo i rzeczowo - oddając własne, jeszcze nie znoszone ubrania. Wnuk pomaga w sprzątaniu: trzepie dywany i myje okna. Wnuczka ma chłopaka $\mathrm{w}$ pobliżu, więc po spotkaniach $z$ nim nocuje u pani Ludmiły, chodzą razem na zakupy. Pani Ludmiła, motywowana chęcią pomocy i rewanżu, piecze ciasta na imieniny, przygotowuje jedzenie na święta, robi zakupy dla córki, korzystając z promocji w supermarketach. Mamy tu więc intensywność kontaktu, czyli częste współbycie, mimo osobnego zamieszkania, współdziałanie i współzależność. Odmiennie niż we wspólnocie, tu mamy do czynienia z użytecznością na rzecz konkretnych osób, a nie działaniem na rzecz wyższej wartości (na przykład ziemi), co zachowało się w postawie przywołanych wcześniej beskidzkich emerytów. Jednak oczywistość współdziałania jest bezrefleksyjna.

Po śmierci męża pozycja pani Ludmiły w rodzinie obniżyła się, a ona sama stała się przedmiotem opieki: jakby maż̇̇yt, to [...] moglibyśmy pomóc, a ja sama, to jeszcze mnie pomagaja nieraz, i tu następują opowieści o tym, jak rodzina $z$ troski kontroluje, gdzie pani Ludka przebywa, oraz o tym, jak kupili jej lodówkę, gdy narzekała na starą. Komplementarność w rodzinie współzależnej polega więc na wyraźnych stosunkach władzy-zależności określonych wysokością wkładu we wspólnotę.

Taki sposób życia codziennego na starość nazwałam modele m uży teczności i unikania bezczynności (Zalewska 2009), ponieważ mechanizm motywujący osobę starą do działań na rzecz wspólnoty przypomina w tym przypadku starość w wielopokoleniowej rodzinie wiejskiej, w której bezczynność zwiastuje zniedołężnienie i śmierć. Pani Ludmiła wychowała się we wspólnocie rodzinnej połączonej silnymi więziami (relacjami instrumentalnymi w terminologii Tamary Hareven): wszystkie ważne przejścia w jej życiu były warunkowane cyklem życia rodziny - małżeństwo, podjęcie pracy, przejście na emeryturę. Obecne współuzależnienie w rodzinie jest dużo słabsze - pobiera niską emeryturę, jest więc częściowo zależna od córki. Należy zapewne do pokolenia, w którym zachodziło „wyjmowanie” $z$ instrumentalnych powiązań rodzinnych.

Historia pani Antoniny jest przykładem sytuacji rodzinnej, w której pokolenia są połączone powiązaniami bliskimi typu relacji, czyli opartymi na „pozostawaniu w kontakcie". Jest ona wdową, urodziła się dekadę przed wojną, jej ojciec był zamożnym przedsiębiorcą, skończyła studia, większość życia przeżyła w dużym mieście. Pamiętajmy, że zgodnie z tym, co piszą Chris Gilleard i Paul Higgs (2005), przemiany więzi rodzinnej wcześniej zachodziły w rodzinach o wyższej pozycji w stratyfikacji społecznej.

Dorosłe życie pani Antoniny poświęcone było życiu rodzinnemu. Przedstawia to jako wybór, a nie bezrefleksyjną oczywistość: większe zadowolenie mi 
dawało to, że ja mam mity dom, że do mnie ludzie chętnie przychodza, że u mnie w domu się chętnie siedzi, tym samym traktuje swój dom jako obiekt własnych świadomych działań, własnego sprawstwa. $Z$ wypowiedzi żony jej wnuka wynika, że pani Tonia miała w rodzinie silny głos doradczy, była czynnikiem sprawczym wielu wydarzeń, dawała opiekę, pocieszenie, rady mężowi, dzieciom, siostrze, teściowej, była „takim zwornikiem tej rodziny”.

Pani Antonina mieszka sama, podczas gdy ona teściową wzięła do siebie. Nie zawsze otrzymuje pomoc w sprzątaniu, nawet gdy kusi wnuki zapłatą. Sama w dzieciństwie uprzedzała potrzeby swojej matki. Można sądzić, że jako dziecko funkcjonowała w modelu użyteczności, w którym dzieci pracują dla rodziny $\mathrm{w}$ miarę sił, jej dzieci zaś były już wychowywane według modelu jednostronnej zależności dzieci od rodziców. Przemianę w stosunkach rodzinnych pani Antonina wiąże z metodami wychowawczymi i z wojną.

Obecnie trudno jest jej pozostawać na pozycji władzy. Zmiana następowała wraz z ograniczeniem sprawności ciała, ze śmiercią męża, z pogorszeniem sytuacji materialnej, w miarę jak dzieci i wnuki zaczęły mieć własne sprawy. Ma niedowład nogi, co zatrzymuje ją $\mathrm{w}$ domu, więc wieczorami dwie godziny spędza telefonując do bliskich. Córka przychodzi raz w tygodniu, wnuk z rodziną co jakieś dziesięć dni, wnuczka - gdy babcia obieca, że zrobi pierogi. Synowa czasem dzwoni, ale nie przychodzi, bo wszystko przypomina jej tu zmarłego męża. Dnie starej kobiety wypełnia polityka i TVN24. W tym przykładzie obserwujemy ograniczenie współbycia do „pozostawania w kontakcie”, nie ma współdziałania i współuzależnienia - spotkania przyjmują formę odwiedzin, a nie posprzątania czy zakupów; kontakty opierają się na wymianie symbolicznej i zapośredniczonej. Jednakże w sytuacji kryzysowej, gdy pani Tonia była chora, relacje zaczęły funkcjonować jak więzi: córka pomagała „we wszystkim”, siostra robiła zakupy.

Pozycje obu kobiet w rodzinie pozwala opisać model (rys. 1), który nazwałam modelem pozycji w rodzinie (Zalewska 2009):

Pani Ludka znajduje się na pozycji zależności — należy do rodziny opartej na więziach i posiada mniej zasobów w porównaniu z innymi członkami rodziny; historia pani Toni zaś obrazuje przesunięcie z pozycji władzy (silna współzależność, wysokie zasoby) na pozycję samotności (słaba współzależność, niskie zasoby).

Sytuacja pani Antoniny pozwala zrozumieć, w jaki sposób przemiany więzi $\mathrm{w}$ rodzinie, czyli zastąpienie więzi opartej na współbyciu i współpracy relacją opartą na symbolicznej wymianie i „pozostawaniu w kontakcie”, pociągają za sobą poczucie osamotnienia. Dzieje się tak za sprawą braku bezpośredniej fizycznej łączności z innymi członkami wspólnoty oraz braku poczucia bycia potrzebnym, współdziałania na rzecz wspólnych celów. Rodzina pani Antoniny raczej nie ma jakichś wspólnych celów, od których zależy przeżycie jej członków. Nawet serdeczne odwiedziny krewnych nie są w stanie dać poczucia jedności 
Model pozycji w rodzinie

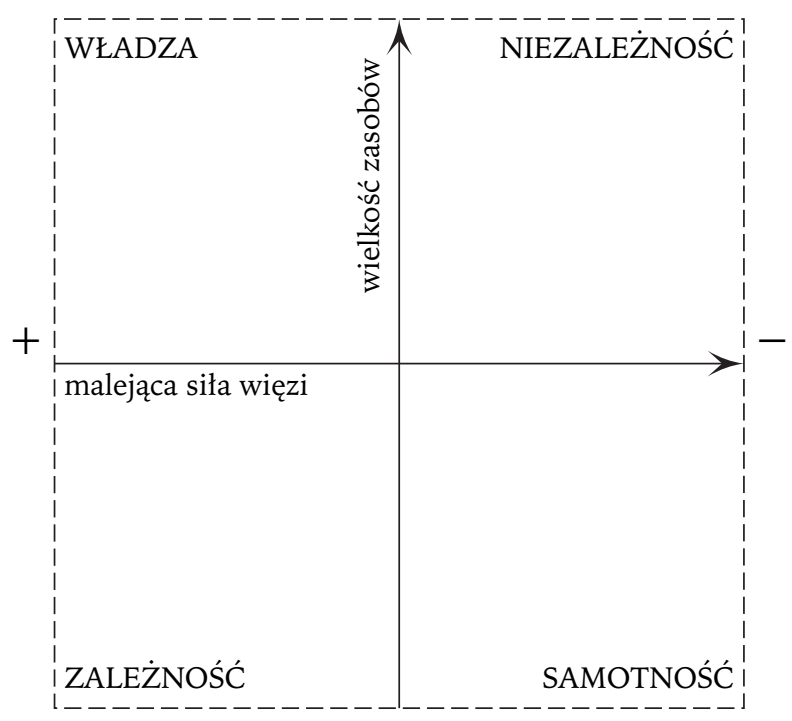

i przynależności do wspólnoty ${ }^{7}$. W samotności spędza czas $38 \%$ emerytów (Czekanowski 2002), potrzebne byłyby dalsze badania, by sprawdzić, w jakim stopniu pod deklaracją sondażową kryje się zjawisko braku więzi społecznej.

Pozycja niezależności w rodzinie zdarza się, gdy potrzeby osób starych mogą zostać zaspokojone poza rodziną, zarówno materialne, jak i związane ze sferą uspołecznienia. W moich badaniach natrafiłam na dwa takie przypadki: wspólnoty projektowej w życiu pani Heleny i społeczności/wspólnoty rówieśniczej w życiu pani Agnieszki. Pani Helena, urodzona tuż przed wojną w rodzinie gospodarskiej, doświadczyła powojennego awansu społecznego. Pod koniec lat pięćdziesiątych zamieszkała w Warszawie, gdzie wyszła za mąż, zdobyła wyższe wykształcenie i znalazła pracę na stanowisku specjalistki. Małżeństwo zakończyło się rozwodem, syn od wielu lat mieszka za granicą. Przez całe życie pani Helena inwestowała w rozwój zawodowy. Po przejściu na emeryturę założyła fundację działającą na rzecz osób starych. Wachlarz działań fundacji był szeroki, pani Helena miała grupę współpracowników, wolontariuszy i beneficjentów skupionych wokół fundacji, nawiązała także współpracę międzynarodową z podobnego typu organizacjami.

Niezwykle silne zaangażowanie pani Heleny w działalność fundacji, która niemalże w całości wypełnia jej właściwie samotne życie, można zinterpretować

7 Przemiana historyczna więzi w relacje dotyczy stosunków między krewnymi poza rodziną nuklearną. Dopóki w domu są dzieci i żyje mąż, dopóty zazwyczaj istnieje wspólnota rodzinna. Samotność zaczyna się zwykle wraz ze śmiercią męża; gdy po stronie dzieci jest przewaga zasobów, to one bardziej kształtują stosunki rodzinne. 
przy użyciu teorii socjalizacji w relacji z obiektem Karin Knorr-Cetiny (1997). Wydaje się, że silne zaangażowanie w obiekt może pełnić analogiczne funkcje jak posiadanie więzi interpersonalnych. W przypadku pani Heleny obiektem byłaby fundacja i działalność na rzecz seniorów. Niewątpliwie mamy tu do czynienia $z$ wzajemnością - beneficjenci działalności pani Heleny reagują wdzięcznością:

„Najbardziej pamiętam... te podziękowania, jak starsze osoby, w czasie... tej akcji przedświątecznej, przed Bożym Narodzeniem, że... modlimy się za was... nasi... kochani... i... wtadza zapomina o nas, wszyscy zapominaja o nas... Dzieci gdzieś tam daleko wyjeżdżają. Też nie zawsze [...] pamiętają. Tylko wy nas ucztowieczacie — mówia”.

Poczucie jedności polega na utożsamieniu się z kategorią emerytów. Ma silny element moralny, któremu wyraz dają poglądy leżące u podłoża założenia fundacji. Pani Helena w prywatyzacji dokonanej po transformacji ustrojowej upatrywała powodów trudnej sytuacji finansowej dzisiejszych emerytów. Jej zdaniem, część pieniędzy z dobrze przeprowadzonej prywatyzacji powinna trafić bezpośrednio do emerytów, którzy osobiście pracowali na prywatyzowane zakłady pracy, fabryki itp. Ponieważ tak się nie stało, istnieje ogromna potrzeba pomocy emerytom i dlatego działalność fundacji jest niezbędna. Oto wymiar moralny zaangażowania pani Heleny w działalność fundacji, jednocześnie można mówić o podzielaniu znaczeń i wartości, oczywiście mamy tu do czynienia raczej z projekcją - pani Helena projektuje swoje poglądy na całą kategorię emerytów i broni interesów, które uznaje za ich interesy. Prawdopodobnie możliwość nawiązania więzi przez zaangażowanie $\mathrm{w}$ obiekt powstaje w pracy o charakterze intelektualnym i projektowym. Rozwój zawodowy oraz zerwanie więzi ze wspólnotą rodzinną $\mathrm{w}$ procesie awansu społecznego ze wsi do Warszawy to czynniki sprzyjające zaangażowaniu we wspólnotę projektową.

Historia życia pani Agnieszki jest dwuczłonowa. Pierwszy człon to „nieciekawe życie”: choroba, bieda, śmierci, trudne więzi - trudy życia w warszawskiej biednej rodzinie robotniczej, drugi to kilkunastoletnie korzystanie $z$ domu dziennego pobytu dla osób starszych przy jednym $z$ ośrodków pomocy społecznej. Powody korzystania z usług tego domu to: braki materialne, zaspokajane głównie poprzez uczestnictwo w darmowych i dofinansowywanych obiadach, oraz potrzeba więzi realizowana w formie aktywnego udziału w życiu codziennym domu. Codziennie około dwustu osób korzystało tam z obiadu, dnie spędzało około czterdziestu osób i do nich należała pani Agnieszka.

Głównym przedmiotem zainteresowania „klubowiczów” była pozycja zajmowana w grupie, wyznaczana na podstawie sytuacji finansowej, wykształcenia, atrakcyjności oraz zaangażowania w życie domu, czyli (1) działalności w samorządzie organizującym imprezy okolicznościowe, wycieczki, wieczorki taneczne, (2) udzielania innym porad i wsparcia. Walka o status toczyła się między kobietami, których było znacznie więcej, w większości niezamężnych, dowodem atrakcyjności było więc posiadanie „chłopaka”. Przejawy atrakcyjno- 
ści to obcisły strój, dekolty, krótkie spódniczki. Pani Agnieszka miała wysoki status: spędzała w domu dużo czasu, angażowała się w problemy innych, działała w elitach władzy, nadawała ton kryteriom atrakcyjności - ubrana według lokalnych reguł oraz przychodząca z „chłopakiem” na wieczorki taneczne.

Dla bywalców domu podstawowym źródłem kontaktu ze społeczeństwem były telewizja (Taniec $z$ gwiazdami, seriale) i gazety codzienne, zwłaszcza „Fakt”. Może dlatego życie pani Agnieszki przypominało młodzieżowy serial:

A poprzednio, przed Jurkiem, jak miatam takiego starszego pana, [...] jak go zapoznałam miat 82 lata, to ja $z$ nim chodziłam czwartek, piatek, sobota i niedziela na wieczorki taneczne. [...] ten ostatni czas się bardzo źle zachowywat $i$ to tak latem żeśmy sie dwa razy pokłócili $[\ldots]$. Czternastego stycznia żeśmy się rozstali. On dostał emeryturę. To byt dawny wojskowy, pan podputkownik. On sobie popit. Przyszedt na wieczorek taneczny, [...] rozmawiatam $z$ nim. $W$ każdym razie on wobec ludzi mówi do mnie - ty żmijo, ty wstrętna żmijo. Ludzie się patrza, bo raczej wszyscy mnie bardzo lubia. A jemu coś odbito. Ja go złapałam tak za ramię tutaj, przyciagnęła do ucha. Mówię — spierdalaj. [...] I wie pani, $i$ odwinętam się na pięcie. Odwróciłam się, usiadtam do stolika, a on przetańczyt tam. Poprosit jakaśs pania. Przyszedt do mnie do stolika, mówi - Niunia, nie gniewaj się. Ja mówię — odejdź ode mnie. I wie pani, od tamtej pory, w ogóle nie chciałam z nim nic mieć wspólnego. Absolutnie. [...] I po prostu zerwałam z nim. Później bytam jakiś czas sama. No, to tak z koleżankami, to tak dwa razy $w$ tygodniu żeśmy chodzity na wieczorki taneczne. No, a później zapoznałam [...] Jurka $i$ od tamtej pory już spotykaliśmy się. Po prostu już żeśmy się polubili, spotykaliśmy się i tak do tej pory jest. I już nigdzie nie chodzę.

Chyba najbardziej słuszna jest tu interpretacja przez wskazanie na mechanizm przejmowania praktyk pochodzących z kultury dominującej, czyli w przypadku pani Agnieszki kultury popularnej propagowanej przez media. „Konsumpcyjność" jest przez nią odtwarzana w krzywym zwierciadle, stosownie do sytuacji materialnej: pani Agnieszka nie nosi kreacji projektantów, lecz ciuszki z bazaru, zamiast do zagranicznych kurortów jeździ na wczasy z opieki społecznej. Naśladowany jest natomiast sposób kształtowania relacji międzyludzkich: rywalizacja o pozycję $\mathrm{w}$ grupie rówieśniczej, waga seksualności, istotność doznawania przyjemności.

Omawiana społeczność spełnia kryteria wspólnot rówieśniczych wyróżnionych przez antropologów: wspólne doświadczenia (starość, emerytura, samotność, bieda, wojenne dzieciństwo, dorosłe życie w PRL), intensywne życie społeczne w dziennym domu pobytu, własne przedstawicielstwo, więzi emocjonalne przejawiające się we wzajemnym udzielaniu wsparcia, mało intensywny kontakt ze światem zewnętrznym, postaci ze świata kultury popularnej jako wspólne symbole. Nie są tu spełnione kryteria więzi społecznej, nie ma mechanizmu, na którym mogłaby się ona opierać, zachęca się raczej do współbycia niż działania dla wspólnego dobra. Ta społeczność rówieśnicza przynależy do szerszej społeczności kultury czasu wolnego, którą spaja rzeczywistość ekranu telewizora. 


\section{W STRONĘ NOWYCH FORM WSPÓLNOTOWOŚCI?}

Pozycję osoby starej $\mathrm{w}$ rodzinie można określić na podstawie charakteru więzi $\mathrm{w}$ tej rodzinie $\mathrm{i}$ wysokości zasobów posiadanych $\mathrm{w}$ porównaniu $\mathrm{z}$ innymi jej członkami. Czynniki te decydują, w jakim stopniu starość w rodzinie zbliża się do modelowych pozycji skrajnych: władzy, zależności, samotności i niezależności. Kontekst historyczny może świadczyć o „rozluźnianiu” więzi rodzinnych i przekształcaniu ich w relacje. We wspólnocie rodzinnej istnieje współdziałanie, współzależność i współbycie, w rodzinie opartej na relacjach zachodzi głównie zapośredniczona wymiana symboliczna. Powiązania rodzinne prawdopodobnie w większej mierze są kształtowane przez osoby mające większe zasoby, tak więc rozluźnienie powiązań $\mathrm{w}$ rodzinie może nastąpić $\mathrm{z}$ nadejściem starości rodziców. W efekcie osoby stare skarżą się na osamotnienie (17\%), spędzają czas samotnie (38\%) lub zwykle na oglądaniu telewizji (80\%) (Czekanowski 2002).

Przemiany więzi w rodzinie towarzyszą przemianom form wspólnotowości: od wspólnot opartych na fizycznej bezpośredniości i geograficznej bliskości do wspólnot symbolicznych i o zapośredniczonej więzi. Proces ten w Stanach Zjednoczonych i Wielkiej Brytanii współwystępował z wyłanianiem się pokolenia kultury młodości. W Polsce przemiany te nie są jeszcze $\mathrm{w}$ pełni zdiagnozowane. Nie do końca wiadomo, jaki jest lokalny kształt indywidualistycznej, zorientowanej na konsumpcję kultury młodości, ani gdzie przebiega ta różnica pokoleniowa, którą w Wielkiej Brytanii i Stanach Zjednoczonych wnikliwie wychwycili Chris Gilleard i Paul Higgs (2005). Czy emeryci w kulturze młodości w ogóle uczestniczą? Przywoływane wyżej badania przeprowadzone w Warszawie pozwoliły dostrzec dwa środowiska wspólnotowości poza rodziną, w różny sposób przynależące do „nowego porządku”: wspólnotę projektową i społeczność kultury czasu wolnego. Wychwycone zostało zjawisko, które może świadczyć o rozłamie: $\mathrm{w}$ grupie badanej do wspólnoty projektowej należała osoba o wysokim kapitale kulturowym; w społeczności kultury czasu wolnego uczestniczyły osoby o niskim kapitale ekonomicznym, kulturowym i społecznym. Czy konsumpcyjna kultura młodości oferuje różny sposób uczestnictwa osobom o różnej pozycji w stratyfikacji społecznej?

W przypadku wspólnoty projektowej można mówić o istnieniu więzi społecznej i działaniu dla dobra wspólnego - według zasad mechanizmu zaangażowania $\mathrm{w}$ relację $\mathrm{z}$ obiektem. Być może jest to mechanizm wykształcony przez współczesne stosunki pracy i charakterystyczny dla zawodów eksperckich, który może się pojawiać także $\mathrm{w}$ przestrzeni pozazawodowej w różnego rodzaju wspólnotach skoncentrowanych wokół projektów. Nie można jednak na razie odpowiedzieć na pytanie, czy mechanizm ten zastępuje mechanizm oparty na zobowiązaniu, czy też po prostu z nim współwystępuje.

Przemiany więzi w rodzinie wydają się zrozumiałe dzięki analizom przejawów ingerencji państwa, rozwoju globalnego rynku i zmian stosunków pracy, 
a diagnoza i zrozumienie nowych form wspólnotowości, w których uczestniczą osoby stare, wciąż jest zadaniem do podjęcia.

\section{BIBLIOGRAFIA}

Anderson Benedict, 1997, Wspólnoty wyobrażone. Rozważania o źródtach i rozprzestrzenianiu się nacjonalizmu, tłum. Stefan Amsterdamski, Znak, Kraków.

Błędowski Piotr, 2002, Gospodarstwa domowe i sytuacja mieszkaniowa ludzi starych, w: Brunon Synak (red.), Polska starość, Wydawnictwo Uniwersytetu Gdańskiego, Gdańsk.

Bourdieu Pierre, Passeron Jean-Claude, 1990, Reprodukcja. Elementy teorii systemu nauczania, tłum. Elżbieta Neyman, Państwowe Wydawnictwo Naukowe, Warszawa.

Czekanowski Piotr, 2002, Rodzina w życiu osób starszych i osoby starsze w rodzinie, w: Brunon Synak (red.), Polska starość, Wydawnictwo Uniwersytetu Gdańskiego, Gdańsk.

Czepulis-Rutkowska Zofia, 2000, Systemy emerytalne a poziom zabezpieczenia materialnego emerytów, IPiSS, Warszawa.

Czerwiński Marcin, 1969, Przemiany obyczaju, Państwowy Instytut Wydawniczy, Warszawa.

Filiciak Mirosław i in., 2010, Mtodzi i media. Etnografia cyfrowego świata, „Kultura Popularna", nr 1.

Finch Janet, 1994, Family Obligations and Social Change, Polity Press, Cambridge.

Gergen Kenneth J., 2009, Nasycone Ja. Dylematy tożsamości w życiu wspótczesnym, tłum. Mirosława Marody, Wydawnictwo Naukowe PWN, Warszawa.

Gilleard Chris, Higgs Paul, 2000, Cultures of Ageing: Self, Citizen and the Body, Pearson Education, Harlow.

Gilleard Chris, Higgs Paul, 2005, Contexts of Ageing: Class, Cohort and Community, Polity Press, Cambridge.

Hareven Tamara K., 1982, The Lifecourse and Ageing in Historical Perspective, w: Tamara K. Hareven, Kathleen J. Adams, Ageing and Life Course Transitions: An Interdisciplinary Perspective, Tavistock Publications, London-New York.

Hazan Haim, 1990, Dimensions of Change: Three Studies of the Construction of Ageing, w: Paul Spencer, Anthropology and the Riddle of the Sphinx: Paradoxes of Change in the Lifecourse, Routledge, London.

Hochschild Arlie R., 2000, An Old Age Community, w: Jaber F. Gubrium, James A. Holstein (red.), Aging and Everyday Life, Blackwell Publishers, Malden, Mass.

Keith Jennie, 1980a, Old Age and Community Creation, w: Christine L. Fry i in., Aging in Culture and Society: Comparative Viewpoints and Strategies, Praeger Publishers, New York.

Keith Jennie, 1980b, „The Best Is Yet To Be”: Toward an Anthropology of Age, „Annual Review of Anthropology", t. 9, s. 339-364.

Knorr-Cetina Karin, 1997, Sociality with Objects: Social Relations in Postsocial Knowledge Societies, „Theory, Culture and Society”, t. 14, s. 1-30.

Lehr Urszula, 2007, U schytku życia. Starość mieszkańców wsi Beskidu Ślaskiego i Podhala, Instytut Archeologii i Etnologii PAN, Warszawa.

Marcus George E., 2003, Użyteczność kategorii uczestnictwa w zmieniających się kontekstach antropologicznych badan terenowych, w: Dorota Wolska, Marcin Brocki (red.), Clifford Geertz - lokalna lektura, Wydawnictwo UJ, Kraków,. 
Marody Mirosława, Giza-Poleszczuk Anna, 2004, Przemiany więzi społecznych. Zarys teorii zmiany spotecznej, Scholar, Warszawa.

Olcoń-Kubicka Marta, 2009, Indywidualizacja a nowe formy wspólnotowości, Scholar, Warszawa.

Olędzki Jerzy, 1991, Murzynowo. Znaki istnienia i tożsamości kulturalnej mieszkańców wioski nadwiślańskiej XVII-XX, Wydawnictwo Uniwersytetu Warszawskiego, Warszawa.

Piotrowski Jerzy, 1973, Miejsce człowieka starego $w$ rodzinie i społeczeństwie, Państwowe Wydawnictwo Naukowe, Warszawa.

Szukalski Piotr, 2002, Przeptywy międzypokoleniowe i ich kontekst demograficzny, Wydawnictwo Uniwersytetu Łódzkiego, Łódź.

Szynkiewicz Sławoj, 1976, Rodzina. Elementy systemu pokrewieństwa, w: Maria Biernacka i in. (red.), Etnografia Polski. Przemiany kultury ludowej, t. 1, Ossolineum, Wrocław.

Tarkowska Elżbieta, 2005, Stary człowiek w Polsce, „Więź”, nr 10.

Zalewska Joanna, 2009, „Stary człowiek w kulturze młodości. Doświadczanie starości wśród warszawskich seniorów”, IFiS PAN, Warszawa, niepublikowana praca doktorska.

Zawistowicz-Adamska Krystyna, 1948, Spoteczność wiejska. Doświadczenia i rozważania $z$ badań terenowych $w$ Zaborowie, Polski Instytut Służby Społecznej, Łódź.

\section{OLD AGE AND CHANGES IN SOCIAL RELATIONSHIPS}

\section{Sum mary}

The article contains an attempt to discuss the "socialisation" of elderly people today. In the $20^{\text {th }}$ century there were considerable changes within the family, the relationships between old parents and adult children underwent gradual transformation - links formerly based on collaboration, dependence and togetherness were replaced by relationships of the type of "staying in contact" and symbolic exchanges. In Poland, especially in the countryside these changes occurred over a longer period than in the west due to the later introduction of retirement and the traditions of extended families. In the $20^{\text {th }}$ century however there occurred at the same time changes in the feelings of communality - instead of relationships based on physical contact and geographical closeness, there developed symbolic groups and communities, often based on indirect means of communication. An effect of the loosening of the ties between the generations in a family and changes in the form of communality is loneliness which is declared by a considerable number of old people in Poland who in their youth had been socialized in communities characterized by physical closeness and joint participation in everyday activities. On the basis of ethnographic studies in Warsaw the article presents four case studies which serve as examples of the lifestyles of four elderly women in families with stronger and looser relationships and in other types of groups/communities: in a daycare centre and non-governmental organization.

\section{Key words/słowa kluczowe}

old age / starość; Third Age / trzeci wiek; community / wspólnota; changes in social relationships / przemiany więzi społecznych; family / rodzina; youth culture / kultura młodości 